\title{
Shewanella decolorationis sp. nov., a dye- decolorizing bacterium isolated from activated sludge of a waste-water treatment plant
}

Correspondence
Guoping Sun
gpsun@gis.sti.gd.cn

Synthetic dyes are manufactured and used in large quantities. These xenobiotic compounds are generally not degraded in conventional waste-water treatment systems when they are used in the textile-dyeing and -printing industry (Conneely et al., 1999; Jian et al., 2000). Beside the unpleasant appearance of dye-polluted waste water, most dyes and their potential breakdown products are toxic (Conneely et al., 1999). As a result, considerable work has been done to assess the use of micro-organisms to deal with such industrial pollutants (Yatome et al., 1991; Nigam

Published online ahead of print on 17 September 2004 as DOI 10.1099/ijs.0.63157-0.

The GenBank/EMBL/DDBJ accession numbers for the $16 \mathrm{~S}$ rRNA and gyrB gene sequences of strain $\mathrm{S}_{12}{ }^{\top}$ are AJ609571 and AJ609572, respectively.

Detailed fatty acid composition data of various Shewanella species and an electron micrograph of strain $\mathrm{S} 12^{\top}$ are available as supplementary material in IJSEM Online. et al., 1996; Zissi et al., 1997; Jian et al., 2000). Members of the genus Shewanella are widely distributed in nature, especially in aquatic environments, such as freshwater and the ocean (Bowman et al., 1997; Ivanova et al., 2001; Bozal et al., 2002). A notable feature of members of this genus is their ability to use a variety of different electron acceptors such as manganese and iron oxides, uranium, thiosulfate and elemental sulfur (Venkateswaran et al., 1999). Most recognized species of the genus have the potential to mediate the co-metabolic bioremediation of halogenated organic pollutants and to reduce heavy metals (Venkateswaran et al., 1998a; Myers \& Nealson, 1988; Lovely \& Phillips, 1988; Perry et al., 1993; Moser \& Nealson, 1996). In this study, we describe a dye-decolorizing bacterial strain $\left(\mathrm{S}_{12}{ }^{\mathrm{T}}\right)$ that was isolated from an activated sludge of a textile-printing wastewater treatment plant in Guangzhou, China.

Strain $S 12^{\mathrm{T}}$ was isolated from activated-sludge samples collected in 2002 from an aerobic reactor of a printing and dyeing waste-water treatment system in Guangzhou, 
China. The activated-sludge samples were inoculated into medium NM9, which is modified M9 medium (Sambrook et al., 1989), containing $10 \%$ nutrient broth (Sambrook et al., 1989) and incubated on a rotary shaker at 150 r.p.m. overnight at $30^{\circ} \mathrm{C}$. The broths were subcultured to the dye medium which was prepared by the addition of appropriate concentrations of the dyes to medium NM9 (medium DNM9). By regular subculturing (5-day intervals) $10 \%$ $(\mathrm{v} / \mathrm{v})$ to a fresh DNM9 medium for a period of 3 months, the enriched populations were serially diluted and plated onto DNM9 agar plates for single-colony isolation. The morphologically distinct colonies showing clear zones around them were purified further and stored on DNM9 agar slants. The morphologically distinct bacterial isolates capable of decolorizing the dye on DNM9 agar plates were then cultivated under aerobic conditions at $30^{\circ} \mathrm{C}$ overnight in nutrient broth. Cells were harvested by centrifugation. The pellets were washed twice in $10 \mathrm{ml}$ PBS ( $\mathrm{pH} \mathrm{8.0)}$ ) and resuspended in $10 \mathrm{ml}$ PBS. Cell suspensions were transferred to fresh DNM9 in replicate tubes to reach an initial cell mass of $0.5-0.6 \mathrm{~g}$ (litre dry cell weight) ${ }^{-1}$ and incubated statically at $30^{\circ} \mathrm{C}$ for dye-decolorization tests. Every hour, $5 \mathrm{ml}$ samples were taken out aseptically and centrifuged at $8000 \mathrm{~g}$ for $10 \mathrm{~min}$. The supernatants were used to determine the percentage decolorization of the respective dyes. The decolorizing activities were expressed in terms of percentage decolorization, which was determined by monitoring the decrease in absorbance at absorption maximum $\left(\lambda_{\max }\right)$ of the respective dyes (i.e. $503 \mathrm{~nm}$ for Fast Acid Red GR, C.I. 27290; $603 \mathrm{~nm}$ for Reactive Brilliant Blue, C.I. 612051). The uninoculated DNM9 supplemented with the respective dye was used as reference. Decolorization activity (\%) was calculated according to the formula decolorization activity $=(A-B) / A \times 100$, in which $A$ is the initial absorbance and $B$ is the observed absorbance.

Strain $\mathrm{S} 12^{\mathrm{T}}$ elicited more than $90 \%$ decolorization activity of Fast Acid Red GR and Reactive Brilliant Blue within $12 \mathrm{~h}$ and was selected and maintained on nutrient broth slopes at $4{ }^{\circ} \mathrm{C}$ or stored at $-20^{\circ} \mathrm{C}$ in nutrient broth supplemented with $20 \%(\mathrm{v} / \mathrm{v})$ glycerol for further studies.

Strain $\mathrm{S} 12^{\mathrm{T}}$ was tested for a number of key characteristics by using standard procedures (Gerhardt et al., 1994), such as the Gram reaction, cell size and morphology (electron microscopy after negative staining with $4 \%$ phosphotungstic acid, $\mathrm{pH} 7 \cdot 0$ ) and tests for cytochrome oxidase and catalase. Acid production from carbohydrates was tested on oxidation-fermentation medium (Atlas, 1993). Furthermore, hydrolysis of starch, gelatin and nitrate reduction were tested following Cowan \& Steel (1993). The temperature range for growth was determined on nutrient agar incubated for 7 days at $4,10,15,20,25,30,37,40$ and $42^{\circ} \mathrm{C}$. The $\mathrm{pH}$ range for the growth of the strain was determined in nutrient broth with $\mathrm{pH}$ values of separate batches of medium adjusted to $5,6,7,8,9,10$ and 11 with $1 \mathrm{M} \mathrm{HCl}$ or $1 \mathrm{M} \mathrm{NaOH}$. The $\mathrm{pH}$ was not controlled during growth. At the end of exponential phase of growth, the $\mathrm{pH}$ was analysed. Salt-tolerance tests were performed in nutrient broth with the $\mathrm{NaCl}$ concentration ranging from 0 to $10 \%$ $(\mathrm{w} / \mathrm{v})$ on a rotary shaker at 150 r.p.m. for $24 \mathrm{~h}$ at $30^{\circ} \mathrm{C}$.

To test anaerobic respiration, the strain was inoculated into nutrient broth containing an electron acceptor $\left(\mathrm{KNO}_{3}\right.$, $\mathrm{NaNO}_{2}, \mathrm{Na}_{2} \mathrm{~S}_{2} \mathrm{O}_{3}$ or $\mathrm{FeCl}_{3}$ ) at a final concentration of $10 \mathrm{mmol} \mathrm{l}^{-1}$. In addition, $\mathrm{H}_{2} \mathrm{~S}$ production was determined with triple-sugar iron agar. Denitrification was tested in nutrient broth by adding nitrate at $20 \mathrm{mmol} \mathrm{l}^{-1}$ (Brettar et al., 2002). Additional phenotypic characteristics were determined by using the Biolog microbial identification system (Venkateswaran et al., 1999). Dissimilatory iron reduction was tested on a defined medium supplemented with $30 \mathrm{mM}$ lactate as carbon and energy source and $50 \mathrm{mM} \mathrm{Fe}(\mathrm{III})$ citrate as terminal electron acceptor (Lovely \& Phillips, 1988).

Fatty acid analysis was carried out according to Song et al. (2000). Cells were cultivated overnight in liquid LuriaBertani (LB) broth medium (Sambrook et al., 1989) at $30^{\circ} \mathrm{C}$ with vigorous shaking. Cellular fatty acid methyl esters were extracted with solution I ( $45 \mathrm{~g} \mathrm{NaOH}$ in $150 \mathrm{ml}$ methanol and $150 \mathrm{ml} \mathrm{H}_{2} \mathrm{O}$ ) and boiling for $30 \mathrm{~min}$, solution II $\left(190 \mathrm{ml} \mathrm{HCl}\right.$ in $275 \mathrm{ml}$ methanol and $135 \mathrm{ml} \mathrm{H}_{2} \mathrm{O}$ ) at $80 \pm 1{ }^{\circ} \mathrm{C}$ for $10 \mathrm{~min}$, solution III $(200 \mathrm{ml}$ hexane and $200 \mathrm{ml}$ ether) with vigorous shaking for $10 \mathrm{~min}$ and then cooled on ice. Extracts were analysed by using a Hewlett Packard model HP6890 gas chromatograph equipped with a flame-ionization detector HP CHEMSTATION version A 5.01 and an Ultra- 2 column $(0 \cdot 2 \mathrm{~mm}$ i.d.; $25 \mathrm{~m}$ long). Hydrogen was used as the carrier gas. Fatty acid peaks were identified and quantified by comparing the results with the patterns from other micro-organisms, using MIDI System software (version 3.2).

For quinone analysis, strain $S 12^{\mathrm{T}}$ and the reference strain DSM $6067^{\mathrm{T}}$ were grown in $500 \mathrm{ml}$ fresh LB medium and incubated with shaking at 150 r.p.m. for $24 \mathrm{~h}$ at $30^{\circ} \mathrm{C}$. Cells were twice extracted with chloroform/methanol $(2: 1, \mathrm{v} / \mathrm{v})$ by lyophilization by the method of Minnikin et al. (1984). Quinones were separated by HPLC and individually identified by MS (Nishijima et al., 1997).

Chromosomal DNA was isolated and purified according to the method of Marmur (1961). The G+C content was determined by thermal denaturation (Marmur \& Doty, 1962). Levels of genetic relatedness were determined by the fluorometric microdilution plate method (Ezaki et al., 1988; Sawabe et al., 1998). 16S rRNA and gyrB gene sequences were determined as reported previously (Yamamoto \& Harayama, 1995). The sequences amplified from strain $\mathrm{S} 12^{\mathrm{T}}$ were compared with those in the GenBank nucleotide database by using online BLAST searches. Phylogenetic trees were constructed according to three different methods (BIONJ, maximum likelihood and maximum parsimony). For the neighbour-joining analysis, a distance matrix was calculated according to Kimura's two-parameter correction model. Bootstrap resampling was done using 1000 
replications, BIONJ and Kimura's two-parameter correction model. BIONJ was used according to Gascuel (1997) and the maximum-likelihood and maximum-parsimony programs were from the PHYLIP package, version 3.573c (Felsenstein, 1995). The phylogenetic trees were drawn using NJPLOT (Perrière \& Gouy, 1996) and ClarisDraw software for Apple MacIntosh. The domains used to construct phylogenetic trees were regions of the small-subunit rRNA gene sequences available for all sequences and excluding positions likely to show homoplasy.

Morphological, physiological and biochemical characteristics of strain $\mathrm{S} 12^{\mathrm{T}}$ are summarized in the species description below and in Table 1 . Strain $\mathrm{S}_{12}{ }^{\mathrm{T}}$ simultaneously contained both menaquinones and ubiquinones as isoprenoid quinones. This profile has been also observed in other Shewanella species (Venkateswaran et al., 1999; Bozal et al., 2002). The major menaquinone of strain $\mathrm{S}_{12} 2^{\mathrm{T}}$ was
MK-7 (98 \%), with MK-8 (2\%) as a minor component. The ubiquinones detected in strain $\mathrm{S} 12^{\mathrm{T}}$ were Q-6 (4\%), Q-7 (30\%) and Q-8 (66\%). The fatty acid composition of the novel isolate is available as supplementary material in IJSEM Online. The fatty acid profile observed for the novel strain is in accordance with the profiles of other Shewanella strains (Ziemke et al., 1998; Venkateswaran et al., 1999; Ivanova et al., 2001; Brettar et al., 2002). The major fatty acids of the novel isolate were $15: 0,16: 0$, iso-15:0 and $16: 1 \omega 7 c$. Palmitoleic acid $(16: 1 \omega 7 c)$ was the most abundant monounsaturated fatty acid found in the novel isolate. Strain $\mathrm{S} 12^{\mathrm{T}}$ synthesized large amounts of straightchain saturated fatty acids followed by terminally branched saturated and monounsaturated fatty acids, as found in Shewanella woodyi (Venkateswaran et al., 1999; Makemson et al., 1997).

A 1448 bp fragment of the $16 \mathrm{~S}$ rRNA gene of strain $\mathrm{S} 12^{\mathrm{T}}$

Table 1. Phenotypic characteristics of various Shewanella species

Species: 1, Shewanella decolorationis sp. nov. strain S12 $;$ 2, S. baltica NCTC 10735 ${ }^{\mathrm{T}}$ (Ziemke et al., 1998); 3, S. denitrificans OS217 ${ }^{\mathrm{T}}$ (Brettar et al., 2002); 4, S. frigidimarina ACAM 591 ${ }^{\mathrm{T}}$ (Venkateswaran et al., 1999; Bowman et al., 1997); 5, S. japonica KMM 3299 ${ }^{\mathrm{T}}$ (Ivanova et al., 2001); 6, S. livingstonensis LMG $19866^{\mathrm{T}}$ (Bozal et al., 2002); 7, S. olleyana ACEM $9^{\mathrm{T}}$ (Skerratt et al., 2002); 8, S. oneidensis ATCC 700550 ${ }^{\mathrm{T}}$ (Venkateswaran et al., 1999); 9, S. putrefaciens ATCC 8071 ${ }^{\mathrm{T}}$ (Nozue et al., 1992; Venkateswaran et al., 1999; Satomi et al., 2003). ND, No data.

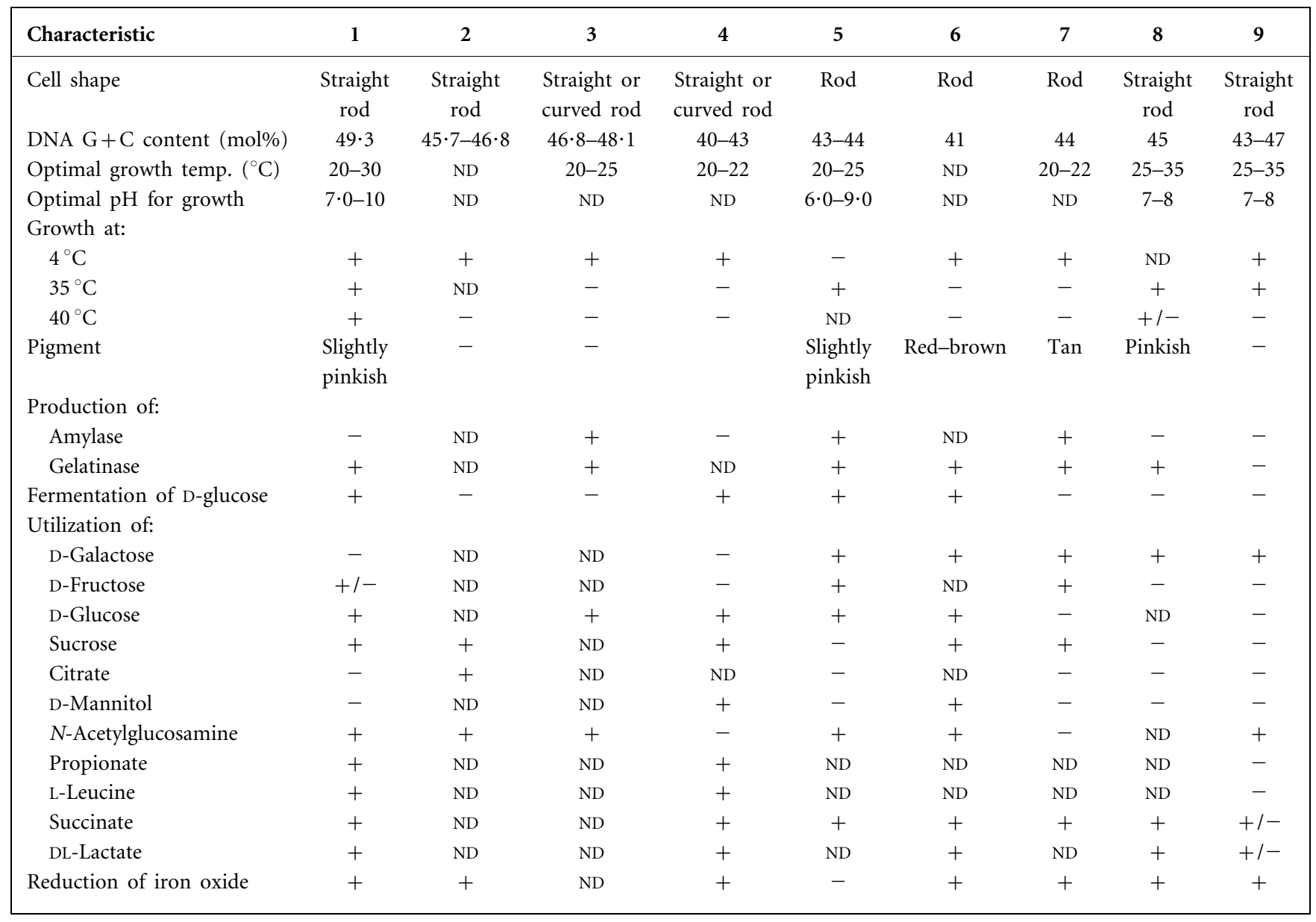


was amplified and sequenced. This sequence was compared with those of the type strains of 20 Shewanella species. The phylogenetic analysis showed that strain $\mathrm{S}_{12}{ }^{\mathrm{T}}$ is most closely related to Shewanella baltica and Shewanella putrefaciens, with 98 and $97 \%$ sequence similarity, respectively. Moreover, some previous workers have reported that the identity of 16S rRNA gene sequences is not a sufficient criterion to guarantee species identity for some bacteria such as those belonging to the genera Bacillus, Vibrio, Pseudomonas, Aeromonas and Shewanella (Fox et al., 1992; Yamamoto \& Harayama, 1995; Venkateswaran et al., 1998b, 1999; Yáñez et al., 2003). On the other hand, the gyrB gene has been employed as a high-resolution molecular identification marker for distinguishing phylogenetic relationships at the species level (Venkateswaran et al., 1999; Satomi et al., 2003; Yáñez et al., 2003). Therefore, the gyrB sequence data were employed to analyse the phylogenetic position of the novel isolate. BLAST searches showed that the novel isolate was positioned in the S. putrefaciens-Shewanella oneidensis cluster. Analysis of gyrB sequences indicated that $87 \%$ similarity was seen between strain $\mathrm{S}_{1} 2^{\mathrm{T}}$ and S. putrefaciens. Venkateswaran et al. (1999) considered a species cut-off value for $g y r B$ sequences is $90 \%$. Phylogenetic trees constructed by using the neighbour-joining method and $16 \mathrm{~S}$ rRNA and $g y r B$ gene sequences are shown in Fig. 1.

The DNA G + C content of strain $\mathrm{S} 12^{\mathrm{T}}$ was $49 \cdot 3 \mathrm{~mol} \%$ (Table 1), which is within the range described for the genus Shewanella (39-55 mol\%; Venkateswaran et al.,
1999). DNA from strain $S 12^{\mathrm{T}}$ showed $41 \cdot 8$ and $41 \cdot 9 \%$ DNA relatedness to the DNA of the two phylogenetically closest strains S. baltica DSM $9439^{\mathrm{T}}$ and S. putrefaciens DSM $6067^{\mathrm{T}}$, respectively. These data are in agreement with the conclusion that strain $S 12^{\mathrm{T}}$ belongs to a novel species of the genus Shewanella, on the basis that strains with DNA reassociation values of less than $70 \%$ belong to separate species (Wayne et al., 1987).

Strain $\mathrm{S} 12^{\mathrm{T}}$ can be distinguished easily from $S$. baltica (Ziemke et al., 1998) and S. putrefaciens (Venkateswaran et al., 1999) by its growth at $40^{\circ} \mathrm{C}$ and its ability to ferment glucose. The strain can also be differentiated from $S$. baltica by its inability to utilize citrate and D-mannitol and from S. putrefaciens by its ability to produce gelatinase and utilize D-glucose, sucrose, propionate and L-leucine and its inability to utilize D-galactose (Table 1). Thus, phylogenetic analyses of $16 \mathrm{~S}$ rRNA and gyrB gene sequences are consistent with the results of DNA-DNA hybridization experiments and phenotypic characteristics in suggesting that strain $S 12^{\mathrm{T}}$ is a representative of a novel species of the genus Shewanella, for which the name Shewanella decolorationis sp. nov. is proposed.

\section{Description of Shewanella decolorationis sp. nov.}

Shewanella decolorationis (de.co.lo.ra.ti.on'is. L. gen. $\mathrm{n}$. decolorationis of discoloration).

\section{S rRNA}

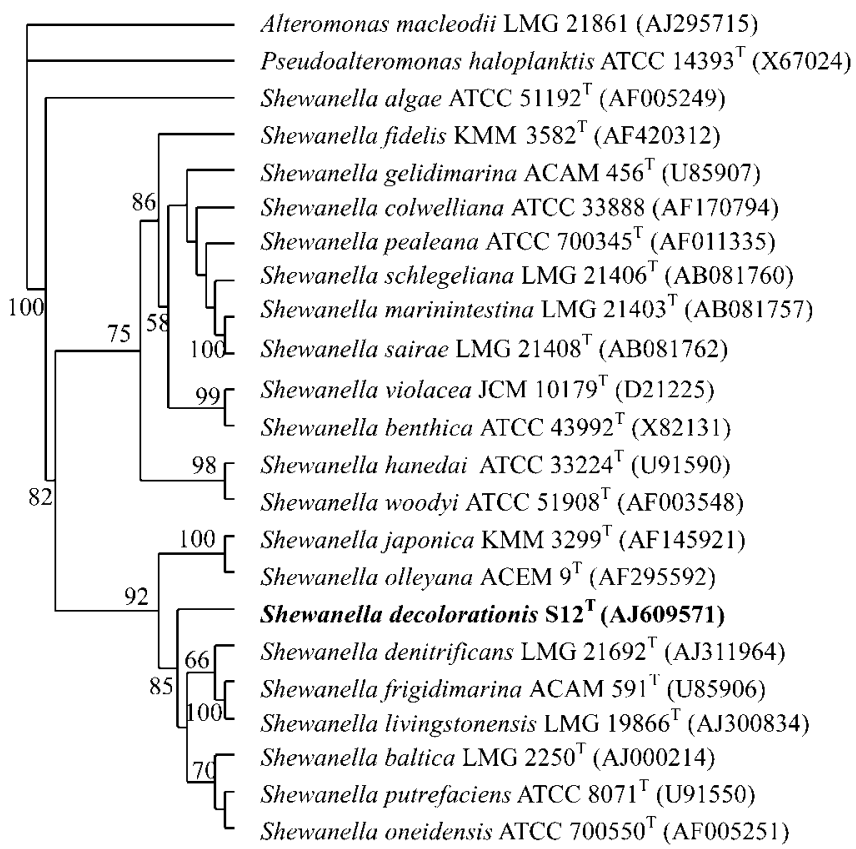

gyrB

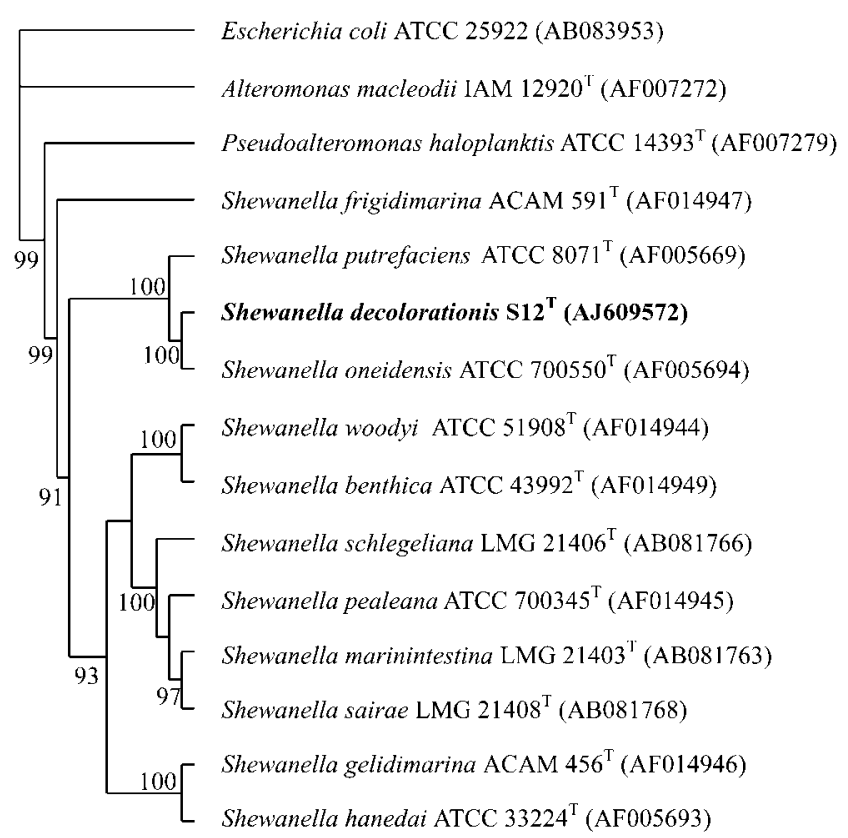

Fig. 1. Phylogenetic trees of the genus Shewanella based on $16 \mathrm{~S}$ rRNA and gyrB gene sequences. The trees were constructed by using the neighbour-joining method. GenBank/EMBL/DDBJ accession numbers are given in parentheses; the sequences determined in this study are in bold type. 
Cells are Gram-negative, polarly flagellated with a single flagellum, straight rods that are $0 \cdot 6-1 \cdot 0 \mu \mathrm{m}$ in width and $1 \cdot 0-4 \cdot 0 \mu \mathrm{m}$ in length. Cells occur singly or in pairs and filaments $7 \mu \mathrm{m}$ long are observed after $24 \mathrm{~h}$ incubation in liquid medium. Neither endospores nor capsules are formed. Oxidase- and catalase-positive. Young colonies are circular, transparent and non-pigmented to slightly pinkish on nutrient broth agar. The $\mathrm{pH}$ range for growth is $7 \cdot 0-10 \cdot 0$, with an optimum at $\mathrm{pH} 8 \cdot 0$. The growth temperature range is $4-40^{\circ} \mathrm{C}$, with an optimum around 20 $30^{\circ} \mathrm{C}$. $\mathrm{NaCl}$ supports growth but is not required. Growth is observed at salinities from 0 to $5 \%$. Positive for hydrolysis of gelatin, Tween 80 and Tween $40 . \mathrm{H}_{2} \mathrm{~S}$ is produced from thiosulfate. Cells are able to reduce nitrate, nitrite, ferric compounds and thiosulfate with lactate or acetate as electron donor. Fermentation of D-glucose is observed. Growth occurs on D-glucose, sucrose, cellobiose, $\mathrm{N}$ acetylglucosamine, propionate, L-leucine, methyl pyruvate, succinate, mono-methyl succinate, formic acid, DLlactate, bromosuccinic acid, glycyl-L-aspartate and glycylL-glutamate. Both menaquinones and ubiquinones are present. Predominant menaquinone is MK-7 and predominant ubiquinones are Q-7 and Q-8. The main fatty acids are $15: 0,16: 0$, iso- $15: 0$ and $16: 1 \omega 7 c$. Straight-chain saturated fatty acids are the major fatty acids, followed by terminally branched saturated and monounsaturated fatty acids.

The type strain is $\mathrm{S}^{\mathrm{T}}{ }^{\mathrm{T}}$ (=CCTCC M $203093^{\mathrm{T}}=\mathrm{IAM}$ $\left.15094^{\mathrm{T}}\right)$. The $\mathrm{G}+\mathrm{C}$ content of its DNA is $49 \cdot 3 \%$. Isolated from activated sludge of a textile-printing waste-water treatment plant in Guangzhou, China.

\section{Acknowledgements}

This work was supported by the Chinese National Programs for High Technology Research and Development (project no. 2001AA214111) and the Guangdong provincial Natural Science Fund (project no. 015017)

\section{References}

Atlas, R. M. (1993). Handbook of Microbiological Media, p. 684. Edited by L. C. Parks. Boca Raton, FL: CRC Press.

Bowman, J. P., McCammon, S. A., Nichols, D. S., Skerratt, J. H., Rea, S. M., Nichols, P. D. \& McMeekin, T. A. (1997). Shewanella gelidimarina sp. nov., and Shewanella frigidimarina sp. nov., novel Antarctic species with the ability to produce eicosapentaenoic acid $(20: 5 \omega 3)$ and grow anaerobically by dissimilatory Fe(III) reduction. Int J Syst Bacteriol 47, 1040-1047.

Bozal, N., Montes, M. J., Tudela, E., Jiménez, F. \& Guinea, J. (2002). Shewanella frigidimarina and Shewanella livingstonensis sp. nov. isolated from Antarctic coastal areas. Int J Syst Evol Microbiol 52, 195-205.

Brettar, I., Christen, R. \& Höfle, M. G. (2002). Shewanella denitrificans sp. nov., a vigorously denitrifying bacterium isolated from the oxicanoxic interface of the Gotland Deep in the central Baltic Sea. Int J Syst Evol Microbiol 52, 2211-2217.
Conneely, A., Smyth, W. F. \& McMullan, G. (1999). Metabolism of the phthalocyanine textile dye remazol turquoise blue by Phanerochaete chrysosporium. FEMS Microbiol Lett 179, 333-337.

Cowan, S. T. \& Steel, K. J. (1993). Manual for the Identification of Medical Bacteria, 3rd edn. Edited and revised by G. I. Barrow \& R. K. A. Feltham. Cambridge: Cambridge University Press.

Ezaki, T., Hashimoto, Y., Takeuchi, N., Yamamoto, H., Liu, S.-L., Miura, H., Matsui, K. \& Yabuuchi, E. (1988). Simple genetic method to identify viridans group streptococci by colorimetric dot hybridization and fluorometric hybridization in microdilution wells. J Clin Microbiol 26, 1708-1713.

Felsenstein, J. (1995). PHYLIP (phylogeny inference package), version 3.57c. Department of Genetics, University of Washington, Seattle, USA.

Fox, G. E., Wisotzkey, J. D. \& Jurtshuk, P., Jr (1992). How close is close:16S rRNA sequence identity may not be sufficient to guarantee species identity. Int J Syst Bacteriol 42, 166-170.

Gascuel, O. (1997). BIONJ: an improved version of the NJ algorithm based on a simple model of sequence data. Mol Biol Evol 14, 685-695.

Gerhardt, P., Murray, R. G. E., Wood, W. A. \& Krieg, N. R. (1994). Methods for General and Molecular Bacteriology. Washington, DC: American Society for Microbiology.

Ivanova, E. P., Sawabe, T., Gorshkova, N. M., Svetashev, V. I., Mikhailov, V. V., Nicolau, D. V. \& Christen, R. (2001). Shewanella japonica sp. nov. Int J Syst Evol Microbiol 51, 1027-1033.

Jian, H., Tso, W., Tso, M., Zhang, X., Xu, M., Deng, S. \& Sun, G. (2000). Broad spectrum decolorizing bacterial strains and their functional plasmids. In Environmental Monitoring and Biodiagnostics of Hazardous Contaminants, pp. 97-104. Edited by M. Healy, D. L. Wise \& M. Moo-Young. Dordrecht: Academic Publishers.

Lovely, D. R. \& Phillips, E. J. (1988). Novel mode of microbial dissimilatory reduction of iron or manganese. Appl Environ Microbiol 51, 683-689.

Makemson, J. C., Fulayfil, N. R., Landry, W., Van Ert, L. M., Wimpee, C. F., Widder, E. A. \& Case, J. F. (1997). Shewanella woodyi sp. nov., an exclusively respiratory luminous bacterium isolated from the Alboran Sea. Int J Syst Bacteriol 47, 1034-1039.

Marmur, J. (1961). A procedure for the isolation of deoxyribonucleic acid from microorganisms. J Mol Biol 3, 208-218.

Marmur, J. \& Doty, P. (1962). Determination of the base composition of deoxyribonucleic acid from its thermal denaturation temperature. J Mol Biol 5, 109-118.

Minnikin, D. E., O’Donnell, A. G., Goodfellow, M., Alderson, G. L., Athalye, M., Schaal, A. \& Parlett, J. H. (1984). An integrated procedure for the extraction of bacterial isoprenoid quinines and polar lipids. J Microbiol Methods 2, 233-241.

Moser, D. P. \& Nealson, K. H. (1996). Growth of the facultative anaerobe Shewanella putrefaciens by elemental sulfur reduction. Appl Environ Microbiol 62, 2100-2105.

Myers, C. R. \& Nealson, K. H. (1988). Bacterial manganese reduction and growth with manganese oxide as the sole electron acceptor. Science 240, 1319-1321.

Nigam, P., Singh, D. \& Marchant, R. (1996). An investigation of the biodegradation of textile dyes by aerobic and anaevolic microorganisms. In Environmental Biotechnology, Principles and Applications, pp. 278-287. Edited by M. Moo-Young, W. A. Amderson \& A. M. Chakrabarty. Dordrecht: Academic Publishers.

Nishijima, M., Araki-Sakai, M. \& Sano, H. (1997). Identification of isoprenoid quinones by frit-FAB liquid chromatography-mass spectrometry for the chemotaxonomy of microorganisms. J Microbiol Methods 28, 113-122. 
Nozue, H., Hayashi, T., Hashimoto, Y., Ezaki, T., Hamasaki, K., Ohwaka, K. \& Terawaki, Y. (1992). Isolation and characterization of Shewanella alga from human clinical specimens and emendation of the description of S. alga Simidu et al. 1990, 335. Int J Syst Bacteriol 42, 628-634.

Perrière, G. \& Gouy, M. (1996). WWW-query: an on-line retrieval system for biological sequence banks. Biochimie 78, 364-369.

Perry, K. A., Kostka, J. E., Luther, G. W., III \& Nealson, K. H. (1993). Mediation of sulfur speciation by a Black Sea facultative anaerobe. Science 259, 801-803.

Sambrook, J., Fritsch, E. F. \& Maniatis, T. (1989). Molecular Cloning: a Laboratory Manual, 2nd edn. Cold Spring Harbor, NY: Cold Spring Harbor Laboratory.

Satomi, M., Oikawa, H. \& Yano, Y. (2003). Shewanella marinintestina sp. nov., Shewanella schlegeliana sp. nov. and Shewanella sairae sp. nov., novel eicosapentaenoic-acid-producing marine bacteria isolated from sea-animal intestines. Int J Syst Evol Microbiol 53, 491-499.

Sawabe, T., Makino, H., Tatsumi, M., Nakano, K., Tajima, K., Iqbal, M. M., Yumoto, I., Ezura, Y. \& Christen, R. (1998). Pseudomoalteromonas bacteriolytica sp. nov., a marine bacterium that is the causative agent of red spot disease of Laminaria japonica. Int J Syst Bacteriol 48, 769-774.

Skerratt, J. H., Bowman, J. P. \& Nichols, P. D. (2002). Shewanella olleyana sp. nov., a marine species isolated from a temperate estuary which produces high levels of polyunsaturated fatty acids. Int J Syst Evol Microbiol 52, 2101-2106.

Song, Y.-J., Yang, R.-F., Guo, Z.-B., Zhang, M.-L., Wang, X.-H. \& Zhou, F. (2000). Distinctness of spore and vegetative cellular fatty acid profiles of some aerobic endospore-forming bacilli. J Microbiol Methods 39, 225-241.

Venkateswaran, K., Dollhopf, M. E., Aller, R., Stackebrandt, E. \& Nealson, K. H. (1998a). Shewanella amazonensis sp. nov., a novel metal-reducing facultative anaerobe from Amazonian shelf muds. Int J Syst Bacteriol 48, 965-972.

Venkateswaran, K., Dohmoto, N. \& Harayama, S. (1998b). Cloning and nucleotide sequence of the gyrB gene of Vibrio parahaemolyticus and its application in detection of this pathogen in shrimp. Appl Environ Microbiol 64, 681-687.

Venkateswaran, K., Moser, D. P., Dollhopf, M. E. \& 10 other authors (1999). Polyphasic taxonomy of the genus Shewanella and description of Shewanella oneidensis sp. nov. Int J Syst Bacteriol 49, 705-724.

Wayne, L. G., Brenner, D. J., Colwell, R. R. \& 9 other authors (1987). International Committee on Systematic Bacteriology. Report of the ad hoc committee on reconciliation of approaches to bacterial systematics. Int J Syst Bacteriol 37, 463-464.

Yamamoto, S. \& Harayama, S. (1995). PCR amplification and direct sequencing of $\operatorname{gyrB}$ genes with universal primers and their application to the detection and taxonomic analysis of Pseudomonas putida strains. Appl Environ Microbiol 61, 1104-1109.

Yatome, C., Ogawa, T., Hayashi, H. \& Ogawa, T. (1991). Microbial reduction of azo dyes by several strains. J Environ Sci Health 26, 471-485.

Yáñez, M. A., Catalán, V., Apráiz, D., Figueras, M. J. \& MartínezMurcia, A. J. (2003). Phylogenetic analysis of members of the genus Aeromonas based on gyrB gene sequences. Int J Syst Evol Microbio 53, 875-883.

Ziemke, F., Höfle, M. G., Lalucat, J. \& Roselló-Mora, R. (1998). Reclassification of Shewanella putrefaciens Owen's genomic group II as Shewanella baltica sp. nov. Int J Syst Bacteriol 48, 179-186.

Zissi, U., Lyberatos, G. \& Pavlou, S. (1997). Biodegradation of p-aminoazobenzene by Bacillus subtilis under aerobic conditions. J Ind Microbiol Biotechnol 19, 49-55. 